Teaching and Learning, Vol 4, No. 3, 2008

\title{
The Observed Impact of Teachers' Capacities on Learning Community Implementation: A Participant-Observer Case Study
}

\author{
Sonya Pancucci: Brock University, Canada
}

\begin{abstract}
I am interested in understanding how Ontario elementary teachers use their capacities to inform learning community implementation. To answer this question I conducted two sets of interviews and recorded my daily observations of 15 elementary school teachers and 4 administrators in research journals and field logs. My dissertation work was completed over a 4 month period during the 2006-2007 Academic School Year as a participant-observer in two different school districts (one Catholic and one Public School Board) in Ontario, Canada. The learning community model is purported to produce effective professional development that improves teaching and learning within schools (DuFour, 2004; DuFour \& Eaker, 1998; Fullan, 1995; Louis, Kruse, \& Marks, 1996; Scribner et al., 1999; Skytt, 2003). By examining how teachers' capacities guided and sustained the process in two elementary schools in two school districts I anticipated determining some key characteristics that ultimately may provide a framework for learning community professional development implementation at the local school level.

\section{Background to the Study}

In learning organizations like schools, continuous learning is promoted through using professional development as the vehicle for change (Hord, 1997). Currently, the professional development model of choice for many school boards in Canada and the United States is the learning community model (DuFour, 2004; Dufour \& Eaker, 1998; Skytt, 2003). The learning community model is based on a social constructivist view of human development founded on post-modern and critical theory ideologies (Mitchell \& Sackney, 2000, p. 130). The learning community is more than a particular ideology; it also brings the wholeness worldview for schools (Sergiovanni, 2000), communities of practice, and capacity building (Lambert, 1998) into professional practice. It is my premise that leadership in pursuit of learning and building capacity for learning and improving pedagogy can be determined by looking at actual lessons taught, their impact, student results, and understandings. This can be described as Starratt's (2003) curriculum of community (p. 233), or as Mitchell and Sackney's curriculum of capacity (p. 3). The learning community model has been shown to produce improvement in teaching and learning in schools (Hord, 2001) and within the current reform environment, many school boards in Canada are basing their school improvement plans on effective schools research that promotes the importance of professional development of teachers for educational change (DuFour \& Eaker, 1998; Goldberg, 2006).

Education changes at a rapid pace and in this context it is especially important to focus on improving teaching pedagogy. This situation requires focusing on ongoing professional development, which takes advantage of teachers' leadership capacity in the development of professional learning communities and supports ongoing professional learning. This process involves deconstruction of the espoused theory, belief system, set of assumptions, and values that are publicly declared and held by a school culture. Once these have been broken down into their constituent parts, such as effective practices, they
\end{abstract}


can be reconstructed into a theory-in-use, a belief system, set of assumptions, and values that are actually followed in professional practice and which need to be aligned to help achieve the goal of improved teaching and learning. Often the theory-in-use is not aligned with the espoused theory or best practice rhetoric, which results in a great deal of inconsistency in beliefs and teaching practices (Fullan, 2003; Fullan, 2000; Mitchell \& Sackney, 2000). One method for avoiding this pitfall is to examine effective schools research because it spans 30 years and supports the notion that effective schools actively plan for continuous school improvement and the mission "Learning for All - Whatever it Takes" (DuFour \& Eaker, 1998; Lezotte \& McKee, 2002).

In Canada there has been a long history of school improvement and effective schools research to assess this process. Unfortunately school reform has failed to effect change at least in part because policy makers and leaders have ignored the complexity of human interactions in education and have focused on theory, rationality, and the cognitive aspects of the change process (Cavanagh \& Dellar, 2001) rather than the emotional component, which Sergiovanni (2005) calls the heartbeat of education. The emotional component of school improvement is the key to the change process because it focuses on hope, which is defined as "unwarranted optimism in the face of seemingly insurmountable odds" (Hulley \& Dier, 2005, p. 200). Leadership and learning strengthen the heartbeat so the school can grow and serve its purpose of teaching children in the life world, which is the essence of hope. Sergiovanni suggests school success can be achieved by balancing the life world and strengthening the school heartbeat to bring leadership and learning together (p. xii). The success of the learning community model to effect change in teaching and learning is in direct contrast to the many failures seen in education reform over the last 60 years of this change process (DuFour \& Eaker, 1998; Fullan, 2000; Glazek \& Sarason, 2007; Hargreaves \& Fink, 2006; Newmann \& Wehlage, 1995).

According to Hord (2001) and Mitchell \& Sackney (2001), the professional development model of choice in Canadian school boards to achieve this goal of improved teaching practice is the learning community. Learning communities are seen to be a powerful staff development approach to produce school improvement because they provide teachers with avenues to work and learn together and to develop more effective teaching practices (Fullan, 1995; Louis, Kruse, \& Marks, 1996; Marks et al., 2000; Pancucci, 2008). Members focus their efforts to improve their teaching and to enhance student learning, achievement, and sustainability ("as long as key personnel stay in place") (Lambert, 2000, p.3). To achieve this goal, teachers collaborate and share practices, implement the strategies, observe one another, and provide feedback (Lambert, 2002). Teachers reflect on the process and revise their practices based on student needs. Learning then is a social and collaborative process where members construct their meaning and sense making from information and experiences that require authentic engagement from its teachers (Marshall, 2006). The learning community setting then is a context where members can improve their capacity and enhance colleagues' capacity by alternately leading and following one another in their journey (Mitchell \& Sackney, 2001).

This model, however, is not without limits. For example, the school improvement process can be difficult due to the intense nature of change (Schlechty, 2001), which is difficult for most teachers. It is easier to maintain the status quo than to examine one's teaching pedagogy and face the challenge of altering those teaching practices (Wasley, 
Hampel \& Clark, 1995, p. 351). Some other problems that groups encounter during change include the tendency of agreeing quickly on a particular issue rather than looking for the ideal solution, or the occurrence of conflicts among members who cannot decide who has the authority to make the final decisions in the change process. Often professional development is mandated through school board policies and this context creates further difficulties because members can feel co-opted into working as a learning community, which could lead to resistance or subversion by teachers (Hargreaves \& Fink, 2006; Pancucci, 2008). Finally, the learning community model could be conservative because of the difficulty of bringing new ideas into an intact group or team who already work well together (Firestone, 1996).

\section{Problem Context}

My work focuses on the learning community professional development model for teachers because I have witnessed it to be a valid professional development model that is also supported by numerous sound research studies (Hord, 2001; Hulley \& Dier, 2005; Mitchell \& Sackney, 2000). In addition, my work is based on the Mitchell and Sackney (2000) model and I feel that it is important to extend upon their model to create a framework for implementation at the school level. This framework would assist school boards involved currently in this change process. The Mitchell and Sackney (2000) model suggests that teachers' capacities are the key to enhancing the practice of teachers, which in turn improves learning for students. The problem, however, is that how these capacities affect the learning community and thereby produce these benefits is not clear. The process of implementing learning communities is difficult and challenging work, which the literature does not currently address in any detail (Pancucci, 2008a). Consequently, this research serves to address a gap in the literature: how teachers' capacities inform the learning community implementation process and a framework of how to use teachers' capacities to implement and sustain learning communities.

In addition, the literature does not provide a picture of what teachers' capacities look like on the ground and my work can assist with this gap in the literature by describing in detail the capacities I observe within individual teachers. Generally, personal capacities are described as individual teacher characteristics, interpersonal characteristics as held by groups of teachers, and organizational characteristics as found within the school's system structures and processes. In this manner I will use a single lens to view the construction of the learning community by studying the teachers who implement and sustain the process and identifying the capacities that they use in this valuable work.

This research is ongoing and to date, I have identified 3 overarching themes in my data: 1. Professional Identity, 2. Investment in the Other, and 3. Institutional Affiliation. Currently, I am using a grounded theory methodology to link my interview and observation data to reveal a clearer understanding of how teachers' capacities informed the formation and ongoing development of the learning community model for professional development within two Ontario elementary schools. During this theorybuilding stage of this research work I will extend the Mitchell \& Sackney (2000) Model for learning communities producing the Pancucci (2008) Framework for learning community implementation. The proposed framework takes the theoretical model for learning community implementation created by Mitchell and Sackney (2000) and expands it by identifying the activities involved in the daily living of that model. In this 
way, I intend to produce a hands-on framework for bringing their theory into the realm of practice. 


\section{References}

Cavanagh, R.F. \& Dellar, G.B. (2001). School improvement: Organisational development or community building? Paper presented at the 2001 Annual Conference for the Australian Association for Research in Education. Retrieved April 27, 2008 from URL: http://www.aare.edu.au/01pap/del01143.htm.

DuFour, R., (2004). What is a "Professional learning community?" Educational Leadership, 61(8), 6-11.

DuFour, R. \& Eaker, R. (1998). Professional learning communities at work: Best practices for enhancing student achievement. Bloomington, Indiana: National Education Service.

Fullan, M. (2003). The moral imperative of school leadership. Thousand Oaks, California: Corwin Press.

Fullan, M. (2000). The three stories of education reform. Kappan, 81(8), 581-584. Retrieved April 27, 2008 from URL: http://www.pdkintl.org/kappan/kful0004.htm.

Fullan, M. (1995). Broadening the concept of teacher leadership. Paper presented for the National Staff Development Council in November 1995.

Glazek, S.D. \& Sarason, S.B. (2007). Productive learning: Science, Art, and Einstein's Relativity in educational reform. Thousand Oaks, California: Corwin Press.

Goldberg, M.F. (2006). Insider's guide to school leadership: Getting things done without losing your mind. San Francisco, California: Jossey-Bass.

Hargreaves, A. \& Fink, D. (2006). Sustainable leadership. San Francisco, California: Jossey-Bass.

Hord, S.L. (2001). Issues ... about change: Professional learning communities: What are they and why are they important? Southwest Educational Development Laboratory, 6(1), 1-8.

Hord, S.L. (1997). Professional learning communities: Communities of continuous inquiry and improvement. Austin, TX: Southwest Educational Development Laboratory.

Hulley, W. \& Dier, L. (2005). Harbors of hope: The planning for school and student success process. Bloomington, Indiana: National Education Service.

Kruse, S.D., Louis, K.S. \& Bryk, A.S. (1995). An emerging framework for analyzing School-based professional community. In K.S. Louis \& S.D. Kruse (Eds.), Professionalism and community: Perspectives on reforming urban schools. Thousand Oaks, CA: Corwin Press.

Lambert, L. (2003). Leadership capacity for lasting school improvement. Alexandria, VA: ASCD.

Lambert, L. (2000). Framing reform for the new millennium: Leadership capacity in schools and districts. Canadian Journal of Educational Administration and 
Policy, 14, 1-15. Retrieved April 26, 2008 from URL: http://www.umanitoba.ca/publications/cjeap/articles/lambert.html

Lezotte, L. W., \& McKee, K. M. (2002). Assembly required: A continuous school improvement system. Okemos, MI: Effective Schools Products, Ltd.

Louis, K.S., Kruse, S.D., \& Marks, H.M. (1996). Schoolwide professional community. In F.M. Newman \& Associates (Eds.). Authentic achievement: Restructuring schools for intellectual quality. (pp. 179-203). San Francisco: Jossey-Bass.

Marks, H.M., Louis, K.S. \& Printy, S. (2000). The capacity for organizational learning. In Leithwood, K. (Ed.), Understanding schools as intelligent systems. (pp. 239265). Stamford, CT: JAI Press.

Marshall, S.P. (2006). The power to transform: Leadership that brings learning and schooling to Life. San Francisco, California: Jossey-Bass.

Mitchell, C. \& Sackney, L. (2000). Profound improvement: Building capacity for a learning community. Lisse, The Netherlands: Swets \& Zeitlinger.

Mitchell, C. \& Sackney, L. (2001). Building capacity for a learning community. Canadian Journal of Educational Administration and Policy, 19, 1-15.

Newmann, F.M. \& Wehlage, G.G. (1995). Successful school restructuring: A report to the public and educators. Madison, WI: University of Wisconsin, Education Center.

Pancucci, S. (2008). Train-the-Trainer: The bricks in the professional learning community scaffold of professional development. International Journal of Social Sciences, 2(1), 14-20.

Pancucci, S. (2008a) - A reflective paper on the implementation of a professional learning community: How teachers' capacities shaped it (Manuscript accepted for publication by WASET $\sim$ February 2008).

Schlechty, P.C. (2001). Shaking up the schoolhouse: How to support and sustain educational innovation. San Francisco, CA: Jossey-Bass.

Scribner, J.P., Cockrell, K.S., Cockrell, D.H., \& Valentine, J.W. (1999). Creating professional communities in schools through organizational learning: An evaluation of a school improvement process. Educational Administrative Quarterly, 35(1), 130-160.

Sergiovanni, T. (2005). Strengthening the heartbeat. San Francisco, CA: Jossey-Bass.

Sergiovanni, T. (2000). The lifeworld of leadership: Creating culture, community, and personal meaning in our schools. San Francisco, CA: Jossey-Bass.

Skytt, J. (2003). Professional learning communities: Empowering teachers in school improvement. Retrieved April 27, 2008 from URL: http://www.teachers.ab.ca/NR/exeres/2AA83A76-FE5F-471E-AFD0BEF8AF8DE3C3.htm.

Starratt, Robert J. (2003). Centering educational administration: Cultivating meaning, community, responsibility. Mahwah, NJ: Lawrence Erlbaum Associates. 
Wasley, P., Hampel, R., \& Clark, R. (1995). When school change influences student Achievement. Unpublished manuscript cited in S. Sarason, Revisiting the culture of the school and the problem of change. New York: Teachers College Press. 